\title{
OPEN-AIR PREACHING: A LONG AND DIVERSE TRADITION
}

\author{
STUART BLYTHE*
}

Acadia Divinity College, Wolfville

\begin{abstract}
For many people, open-air preaching is associated with a particularly limited understanding of the nature of the event. In part this is related to the fact that open-air preaching has received relatively little serious academic study. From a variety of sources, however, it is possible to piece together something of a critically analytic sketch of the practice. This sketch demonstrates that not only can open-air preaching claim longevity but that in turn it is a practice with considerable diversity as open-air preachers seek to make meaning through their gathering and encounter with audiences.
\end{abstract}

KEY WORDS: preaching, open-air preaching, Spurgeon, diverse tradition

\section{Introduction}

There are some customs for which nothing can be pleaded, except that they are very old. In such cases antiquity is of no more value than rust upon a counterfeit coin. It is, however, a happy circumstance when the usage of ages can be pleaded for a really good scriptural practice, for it invests it with a halo of reverence (Spurgeon 1881: 54).

The custom to which Spurgeon was referring in this quote was the practice of open-air preaching sometimes referred to as street preaching. Such preaching was common practice in nineteenth century England. Indeed, in the mid-nineteenth century, open-air preachers were so common, at least in the cities, that one contemporary critic compared them to caterpillars swarming over a leaf in all directions (Lewis 1986: 226). Though dating from the nineteenth century Spurgeon's writing about open-air preaching in this and in an accompanying lecture entitled 'Open Air PreachingRemarks Thereon’ (Spurgeon 1881b) is significant for a number of reasons.

* STUART BLYTHE (PhD 2009, University of Edinburgh) is the former Rector of the International Baptist Theological Study Centre, Amsterdam, and presently Associate Professor of John Gladstone Chair in Preaching and Worship, Acadia Divinity College, Canada. Email: blythe@ibts.eu. 
First, it explicitly deals with the practice of open-air preaching. There is very little academic writing on open-air preaching. When I carried out my own PhD research into this topic from 2003-2009 the main academic writing I identified was that associated with Charles L. Campbell (Blythe 2009). This is found principally in his collaborative writing with New Testament scholar Stanley P. Saunders and entitled, The Word on the Street: Performing the Scriptures in the Urban Context (Saunders and Campbell 2000). Campbell later produced a paper on the theological foolishness of preaching with the title 'The Preacher as Ridiculous Person: Naked Street Preaching and Homiletical Foolishness' (Campbell 2007).

Since then I am only aware of a few articles or chapters that discuss the practice. Edelman uses examples of American street preaching to discuss issues of performing religion in public and the nature of the audience it creates (Edelman 2013). Edwards uses the idea of street preaching in relation to Kierkegaard and emphasises some of the themes of foolishness (Edwards 2017). The insights of both are interesting.

This said, their discussions on the nature of open-air preaching are somewhat limited in terms of the scope of the preaching they consider. The fact that there is only limited academic discussion related to open-air preaching means we are often dependant on literature such as Spurgeon's to gain if only even a historical insight into the practice. I describe such literature, sometimes popular in nature, and written to promote open-air preaching as literature of advocacy.

Second, Spurgeon's writing on open-air preaching is significant because he offers a quite extensive sketch of the history of the practice (Spurgeon 1881). This historical sketch, although often limited in detail, lacking analytical differentiation, and not referencing sources, is yet one of the most comprehensive sketches available. It includes mention of open-air preachers from England, Scotland, Ireland, Wales, Continental Europe, and America. In contrast to this, unlike preaching in general, there is no specific contemporary historical overview of open-air preaching. To be sure, the general preaching histories refer to prominent examples of open-air preaching within their account. That is, they recognise the activity as a historic example of preaching. Be this as it may, they frequently do not treat open-air preaching as a distinct genre.

A third way in which Spurgeon's writing is important: although his work can be described as literature of advocacy he indicates that not all share his enthusiasm for the practice.

I fear that in some of our less enlightened country churches, there are conservative individuals who almost believe that to preach, anywhere except in the chapel would be a shocking innovation, a sure token of heretical tendencies, and a mark of zeal without knowledge. Any young brother who studies his comfort among 
them must not suggest anything so irregular as a sermon outside the walls of their Zion (Spurgeon 1881b: 76).

This comment indicates that opposition to open-air preaching is not something new or simply a result of twenty-first century cultural sensibilities with respect to mission. Indeed, in the contemporary context, open-air preaching is widely associated with negative stereotypes: both in practice and perception. These stereotypes are of angry, haranguing preachers, with little apparent real concern for passers-by.

The negative view of open-air preaching is perhaps given extra potency, in socio-religious contexts, where the very nature and value of preaching itself in church let alone outside is under scrutiny (Stevenson and Wright 2008: 1-11). Open-air preaching, therefore, is not simply a practice which is neglected in academic study but which is often treated with some suspicion.

And a fourth aspect: Spurgeon recognises that open-air preaching is a 'particular' genre of preaching. To be sure, in terms of its biblical and historical validity, Spurgeon wishes to argue that open-air preaching is not a 'shocking innovation' (Spurgeon 1881b). He also acknowledges that openair preaching is an 'irregular' practice. In discussing its relationship to times of renewal and revival, he states that it has sounded the 'wild note' of preaching, less sweet perhaps but more natural than the bird song which occurs in 'cages' (Spurgeon 1881: 69).

Therefore, there is a demonstrated tension between asserting open-air preaching as a valid expression of Christian preaching, it is as old as preaching itself' (Spurgeon 1881: 54), and the recognition of its unconventional nature. Something similar is found in Campbell. He describes the practice as an 'extreme homiletic' which can inform those who occupy pulpits on a Sunday morning (Saunders and Campbell 2000: 104).

To talk about open-air preaching, therefore, is to discuss preaching. It is, however, to discuss a 'particular' genre of preaching, a genre which takes place outside the normal context for preaching, at least in the Global North. This normal context is a congregation gathered for worship, usually in a building. Because of its irregular nature, this 'particular' genre is often neglected-if not disdained-in contemporary writing and practice.

In response to this deficit I expand upon the nineteenth century sketch by Spurgeon (1881) and a much shorter sketch by Campbell (2000: 96-99) to demonstrate something of the long and diverse practice of open-air preaching. My focus will be primarily on the story as related to the context of Scotland, Britain, Western Europe, and North America. My goal is to highlight the longevity, diversity, and complexity of the practice in this context. 


\section{A Long Tradition}

As indicated in the opening quote, one of the claims made by various advocates for open-air preaching is that it has a long history rooted in biblical practice (Ewing 1799; Gibson 1984). Scriptural examples adduced in support of this claim include Moses, Elijah, Isaiah, Amos, Jonah, Jesus, Peter, and Paul. It is a weakness of these writings that there is little scholarly discussion of the individual examples given. There is little consideration of why these biblical characters preached in the open air or the nature of their audiences, such as whether they existed within or beyond the community of faith. The nature of the relationship between such earlier precursors, their significance, the nature of the practices they indicate, and later open-air activity, is not, therefore, discussed in detail. Despite these weaknesses, these writers indicate that open-air preaching, as Christian preaching in general, has roots in practices that pre-date the formation of the New Testament. These practices include Hebrew prophecy, ancient oratory, and the proclamation of the gospel by Jesus and the apostles.

Hughes Oliphant Old in his multi-volume general history of preaching does recognise the biblical precursors specifically for open-air preaching,

John the Baptist was not an institutional preacher who preached because society had given him that responsibility and had provided for him a parish, a pulpit, and a parsonage. John the Baptist was a charismatic preacher whom God's Spirit raised up as he had the prophets, to preach a unique message for a very particular time. Like the Methodists and the Franciscans, like the hermit preachers in the Eastern Orthodox churches, like the Pentecostal preachers of today, John the Baptist preached out-of doors. He preached in the wilderness and people went out to hear him. The voice crying in the wilderness was a very special kind of preaching, and John the Baptist is the biblical figure for this kind of preaching. The voice crying in the wilderness has a special intensity because it is called forth directly by the Holy Spirit. It came from the white-hot burning bush of God's presence. Jesus too, was a charismatic preacher, a voice crying in the wilderness. Jesus could preach in the marketplace, on the mountainside, and beside the sea. Not everyone could do that. It takes a special charisma. Jesus could do it as John the Baptist could (1998:115).

Old identifies open-air preaching as a particular expression of Christian preaching. It is not the dominant expression of preaching which for Old is preaching which occurs in the context of worship and constitutes the primary focus of his study (Old 1998: 3-4). In its peculiarity, however, Old posits open-air preaching as a significant expression of Christian preaching, with varied historic manifestations, rooted in the prophetic tradition, and mediated through John the Baptist and Jesus into contemporary Christian practice. The disruptively prophetic preaching of John the Baptist and Jesus, as paradigmatic for open-air preaching, is also highlighted in Campbell 
(Saunders and Campbell 2000: 97, 104). To be sure, not all histories of preaching begin with the Scriptural narratives and practice. O. C. Edwards argues that there is little in the New Testament including in the practice of Jesus that fits his definition of preaching. He begins his study with reference to a second century sermon by Justin Martyr (Edwards 2004). Those who start with the Scriptures, however, and posit Jesus and other biblical characters as in any way paradigmatic, have to contend with the fact that Jesus and other biblical characters preached outdoors (Osborn 1999: 6,189).

Open-air preaching not only has its roots in the Scriptures but subsequently is an activity which has manifested itself in various ways throughout history. This is demonstrated, albeit again at times without detailed discussion, in sketches provided by the advocates of the practice such as Spurgeon. Moving from the biblical witness Spurgeon goes on to name among others: 'itinerant friars' (Berthold of Ratisbon), Protestant reformers (George Wishart, John Knox), British Puritans (John Bunyan), Scottish Covenanters (Donald Cargill, Richard Cameron), revivalists (John Wesley and George Whitefield), evangelists (Gideon Ouseley, Christmas Evans), and camp-meeting preachers (Spurgeon 1881).

General histories on preaching will at times include accounts of open-air preaching although often simply subsumed under the general category of their definition of preaching. A prominent example of this is O. C. Edwards who defines preaching as,

a speech delivered in a Christian assembly for worship by an authorized person that applies some point of doctrine, usually drawn from a biblical passage, to the lives of the members of the congregation with the purpose of moving them by use of narrative analogy and other rhetorical devices to accept that application and to act on the basis of it (Edwards 2004: 3-4).

He acknowledges the existence of evangelistic and open-air preaching but argues that even these 'exceptions' nearly always occurred within the context of worship (Edwards 2004: 4). One consequence of this approach is to neglect the specific dynamics and contribution of the practice throughout history. Another consequence is to prevent the practice of open-air preaching, as it challenges the dominant understanding of preaching being an event that occurs within the context of a congregation gathered in worship.

One older history of preaching, however, where the author makes an attempt to discuss the specific significance of open-air preaching, is the three volume work by F. R. Webber, A History of Preaching In Britain and America (Webber 1952). Webber discusses open-air preaching because of his conviction that great preaching should include the ability to present 'evangelical truth clearly' (Webber 1952, volume 1: 17). He argues that the open-air preaching of John Wesley (1703-1791) and George Whitefield (1714-1770) 
was part of a long, although forgotten, historic tradition of open-air preaching and its expression created a new interest in preaching, infusing "new life' into the practice of preaching in the eighteenth century (Webber 1952, volume 1: 322, 329-331). Webber gives a significant proportion of his study to preaching in Scotland, 'Celtic' preaching (Webber 1952, volume 1: 29128).

In the second volume, drawing upon earlier works on Scottish preaching (Taylor 1887; Blaikie 1888), he refers extensively to a number of Scottish examples of preaching that took place outdoors. These earlier works do not offer analytical discourse on the nature of open-air preaching as a genre, though Taylor writes about John Livingstone's open-air communion service in 1630, and both authors describe seventeenth century 'fieldpreaching' of the Covenanters (Taylor 1887: 94-99,124-138; Blaikie 1888: 155-184). Webber also includes a minor reference to the late eighteenth and early nineteenth century open-air preaching of the Baptist pioneer James Haldane (Webber 1952, volume 2: 203).

Campbell's summary of open-air preaching brings the story more up-todate than the examples cited by either Spurgeon or Webber. He mentions the Salvation Army, mid-twentieth century Roman Catholic street preachers, the sermons of the proponents of the civil-rights movement and campaigners for nuclear disarmament, 'and the countless individual street preachers who have been proclaiming the Word on the street corners of America up to this very moment' (Saunders and Campbell 2000: 99). His focus is primarily on the United States. One could certainly add the openair preaching in which Campbell himself was involved (Saunders and Campbell 2000: 95-96).

On a quite different theological spectrum, those expressions which have a high online presence, and are associated with Jesse Morrel, Ray Comfort and others (Edelman 2013) should also be mentioned. In Britain, in addition to a plethora of lesser known individuals and activities by congregations, a more extended list could include 'The Open-Air Mission' founded in 1853 (Open-Air Mission 2017), as well as OAC UK, the UK branch of Open Air Campaigners founded in 1968, and originally founded in Australia in 1892 (OAC UK 2017). Names such as George MacLeod (1895-1991) (Blythe 2011) and Donald Soper (1903-1998) (Hunter 1972) also deserve recording.

The history of open-air preaching, therefore, has to be drawn from a variety of individual sources. The writings of advocates demonstrate the longevity of the practice but often lack considered detail and discussion. General histories of preaching often obscure the particular nature of open-air preaching. Together, however, various sources enable a researcher to dis- 
cuss and describe more fully the diverse and complex nature of the historic practice of open-air preaching.

\section{A Diverse Tradition}

In addition to having a significant history, open-air preaching is also of diverse rendition. This diversity is not simply related to the historical sociocultural context in which it occurred, although this is important. Rather, each open-air preaching event is constituted by the dynamic and varied interaction of a number of factors within its context. These variables all play a part in the meaning-making of any particular event. Therefore, to demonstrate the complex nature of open-air preaching, over and against simplistic stereotyping, I will discuss a number of the factors operative in determining the specific nature of any particular open-air preaching event. I will do this with reference to various examples. Both the variables and the examples of open-air preaching should be considered as illustrative rather than in any way exhaustive. Besides, any number of these variables can be at play impacting one another in each and every open-air preaching event.

\section{Status of Preachers}

One differentiating variable in the historic practice of open-air preaching is of course the person of the preacher. While each individual preacher would bring something distinctive in relation to their personality, the focus here is rather on the different status of the preachers. This relates to the extent to which individuals are recognised by the Church, State or social convention, as those who could and should preach. In the Medieval Roman Catholic Church only bishops could preach by right, and priests, members of monastic orders, and mendicant friars required legitimising authority (Edwards 2004: 215-217). Some open-air preachers have been people so recognised, trained, and authorised. Such was the case in thirteenth century Europe, with the establishment of mendicant orders including the Franciscan and Dominican order of 'Preaching Brothers' (Edwards 2004: 212-217). On the other hand, there were the open-air preachers of the Waldenses and Cathars who were considered 'heretical'. Contrary to established norms, they included in their number both lay people and women (Edwards 2004: 212 217). The 'preaching friars' were formed, in part, to counteract their 'unlicensed' preaching. Beverly Mayne Kienzle demonstrates how in some early anti-Waldensian polemics an unauthorized layperson was labelled as a heretic. Female preachers received the same condemnation along with that specific to their gender, and by association heretical male preachers were likened to 'deceitful women' (Kienzle 1998: 104).

The significance of unlicensed open-air preachers in relation to the authorities of church and state correlates to the particular historical context. 
The irregular preachers of the Lollards were regarded as threatening the norms of society (Owst 1926: 54). During some times of Reformation such preaching could lead to threat of bloodshed. Such was the case, for example, with the open-air preaching of George Wishart (1513-1546) during the Reformation in Scotland (Rogers 1876: 278-280). With less danger of bloodshed but still with intensity unlicensed open-air preaching was an important feature of the ministry of the previously mentioned James Haldane. On the one hand, the fact that he preached as a wealthy lay person increased interest in his activities and helped to gather audiences. Writing about the 1797 tour and the visit to Aberdeen, Haldane's biographer writes, 'It might be said that the whole population of Aberdeen turned out by thousands to hear an East India Captain. There was novelty in the fact' (Haldane 1855: 151). On the other hand, because of his lay status this very preaching led to criticism and reaction from representatives of church and state.

In response to petitions from various Presbyteries about the preaching of Haldane and his colleagues the General Assembly of the Church of Scotland on the 28th May 1799 issued a 'Declaratory Act' against unqualified ministers and preachers. This Act refused to recognise ministers not licensed by the Established Church. It also declared that no support should be given by established ministers to such unlicensed preachers (Declaratory Act 1799: 868-869). This was accompanied by a 'Pastoral Admonition', dated 3rd June 1799, which was sent out to be read in churches, warning them against vagrant preachers and those who may engage in establishing Sunday Schools. These actions were not simply supported by the 'Moderates' within the Established Church but also by the 'Evangelicals' many of who were critical of the unlicensed preaching of Haldane and his associates (Haldane 1885: 181). As a consequence the 'Declaratory Act' severed the links between the Evangelicals within the Established Church and the supporters of itinerant open-air preaching (Lovegrove 2000: 78-79). As I have discussed elsewhere, the different reactions to Haldane's open-air preaching contributed to the formation of modern Scottish congregationalism and a stream of Scottish Baptist churches (Blythe 2015).

It has been suggested that open-air preaching has been one of the more inclusive forms of preaching in terms of those permitted to participate, not least with respect to lay people and women (Saunders and Campbell 2000: 105). Significantly, open-air preaching has also been associated with periods of renewal in the Christian Church when various other institutional norms were by definition being called into question (Saunders and Campbell 2000: 101-102, 105). Renewals may have thus created the space for wider involvement. Penelope J. Corfield argues that on the issue of women preaching 'John Wesley's spiritual and organisational radicalism triumphed over his social conservatism' (Corfield 1995: 105). 
Not all those involved in movements for change who supported lay open-air preaching also supported women preaching in the open air. Haldane did not accept that his arguments for lay preaching supported the idea of women preaching to mixed audiences (Haldane 1798: 13). In turn, some renewal groups (such as Methodism) as they became more institutionalised would adopt more restrictive policies-at least until the twentieth century (Stout 1991: 158). Some others, though, such as the Salvation Army, which promoted open-air preaching as an evangelical strategy would build equality in ministry between men and women into the very institutional structures of their organisation (Walker 2001). In so far as a number of the groups who promote and practice open-air preaching today draw from a more conservative or even fundamentalist theology they tend not to support women preaching. Edelman indicates that in his research he could find no examples of contemporary female street preachers (Edelman 2013: 129). This said, Campbell's own discussion, from a different theological perspective, begins with the account of a female street preacher (Saunders and Campbell 2000: 95-96), reminding readers that the dominant story is not the complete story. It may be possible to claim that historically open-air preaching has been more inclusive as to who can preach with respect to women and lay people. Whether that claim holds in the contemporary context is more questionable certainly with respect to women.

One of dynamics of open-air preaching relates to 'who' the preacher is. The significance of this to the meaning-making of the event depends upon the novelty or otherwise of the preacher and the reactions that it evokes from various audiences.

\section{Specific Locations}

Another factor establishing variety in open-air preaching is the specific locations used for preaching and the significance of those locations. For example, in England, there is a contrast between pre-Reformation itinerant 'Lollard' preachers who would preach wherever they could gather an audience (Edwards 2004: 254) and Reformation and post-Reformation preachers, such as William Tyndale (1494-1536) who was preaching 'on the College Green at Bristol' (Moynahan 2003: 24), Hugh Latimer (1485-1555), preaching at the official open air pulpit at St Paul's Cross (Darby 1953: 115), and Archbishop William Laud (1573-1644), preaching from the scaffold on Tower Hill prior to his execution (Bliss 1854: 430-440). All of these people preached in the open air. The locations, however, varied considerably, and in turn the gathered listeners and their expectations as related to these locations would vary.

The significance of a space for open-air preaching can change over time, while retaining associations with earlier usage. St Paul's Cross was originally 
established at the entrance of a burial ground to remind people to pray. It then became a place of public proclamation, developing in significance until in the years of the English Reformation its pulpit became "nothing less than the popular voice of the Church of England, during the most turbulent and creative period in her history' (MacClure 1958: 167). Likewise, after Tower Hill was no longer used for executions, it remained a place of public gathering and continued to be a site for open-air events. It was one of the regular preaching places of the well-known English twentieth-century open-air preacher, Donald Soper (Frost 1996; Hunter 1972). Such locations of public gathering, associated with the expectation of public spectacle, enhance the opportunity for open-air preachers to gather an audience. Soper would also preach at Speaker's Corner in Hyde Park. This is a location known for open-air speakers, including preachers, and this is the very reason people go there (Coomes 2015).

Conversely to the above, other locations can influence the meaningmaking of open-air preaching precisely because they are not necessarily established as places for such activity. This can lead to contests over the right to preach, freedom of speech and religion, and the nature of public space. Such drama can contribute to the event. Haldane again provides a fascinating historical example. During his 1798 tour with Aikman he was threatened with arrest if he preached the following day. In response, he asserted his legal right to preach in public although not necessarily in all places. The drama of the confrontation is captured by his biographers:

He was threatened with imprisonment if he should preach on the following day, as he had announced; but he assured the magistrates that menaces without lawful sanction were of no avail. He would not indeed preach at the cross, or at any place to which just exception might be taken, but in preaching out of doors he infringed no law, and on the contrary was protected by the Toleration Act. 'Depend upon it,' said one of them, 'depend upon it, that you will be arrested'. The reply was characteristic, 'And depend upon it, Sir, I shall be punctual to my appointment.' He was on the ground at the appointed time, and preached to a great audience without molestation (Haldane 1798: 185).

In Haldane's case, similar incidents created greater interest in his preaching and larger crowds turned out because of the controversy (Haldane 1798: 186). Conversely members of the public may resent preachers interrupting public space and welcome the prohibition of open-air preaching. For these reasons in 2007 in the UK the Christian Institute felt it necessary, following a court case, to publish legal advice to the Open Air Mission (Christian Institute 2007).

Implicit in the foregoing but at times explicit, the locations of open-air preaching can carry important symbolic significance which contributes to 
the meaning of the events. The example of George MacLeod illustrates this. Govan Cross was the established centre of Govan and was frequently used as a meeting place for all sorts of activities. As such, it had practical value in gathering an audience. It was, however, also the ancient Christian centre of the area. MacLeod had a replica Celtic Cross erected there in 1937 (Govan Parish Magazine 1937). The next day, he launched his 'Peace Week' openair campaign from that very spot (Govan Press 1937: 1). He would later go to Clydebank and to other sites in Glasgow where there was bomb damage and preach there in the open air to deliberately embody the presence of the church in places facing crises and distress (Ferguson 1990: 188, 239). This seems similar to the practice of Martin Luther King Jr during the Civil Rights movement in America. He, and his associates, "would often rush to the scene of a bombing and hold a service of prayer and preaching in the still smouldering foundation' (Lischer 2005: 33). Later people could not remember what he said but they remembered 'where he said it' (Lischer 2005: 33).

\section{Purpose and Content}

In addition to the specific status of the preacher and the location of the preaching, a third variable that establishes the diverse nature of open-air preaching events is the purpose and content of the sermons. Since the eighteenth century revivalist preaching of Wesley and Whitefield, open-air preaching has been widely associated with evangelism understood as promoting a message of personal salvation. Much subsequent open-air preaching has certainly been of this nature with later practitioners often appealing to the example and success of Wesley and Whitefield (Pike 1888: 183-209, Open-Air Evangelism Training Manual 2006: 10). More, however, is required to be said about the historical variety of content and purpose in open-air preaching.

First, Wesley and Whitefield do not offer a uniform example of evangelistic open-air preaching. They had distinct theologies, their respective Arminian and Calvinistic convictions creating discord between them (Campbell 1991: 125-127). They had different styles. Horton Davies, who with reference to sermon texts, compares and contrasts Wesley and Whitefield and opines, 'Whitefield was ever the orator, Wesley always the don', and again, 'Whitefield was the spell-binding orator and preacher par excellence, while Wesley was the best of pulpit preachers' (Davies 1961: 160, 172). Their preaching had various shared and different social and religious consequences with respect to its outdoor nature, their respective relationships with church authorities, those whom they reached, and in Wesley's case, the movement which he left behind (Fant and Pinson 1971: 2-14, 107-118). In addition, the preaching of Wesley in particular has been associated with so- 
cial reform in respect to issues of poverty, slavery, and alcohol abuse (Thompson 1998). 'The gin shop was the curse of the Industrial Revolution... That Wesley and the Evangelical Revival generally should have preached so often against the evils of drink was for that time prophetic' (Old 2004: 135).

One writer, albeit without substantiation, claims that Wesley's influence was responsible for decline in the consumption of alcohol between 1744 and 1784 (Fant and Pinson 1971: 8). One trajectory which could be pursued regarding the open-air preaching on social topics of Wesley and his itinerants would be to consider them as a form of 'public theology' (Field 2015). As with open-air preaching in general, so in particular, the open-air preaching of Wesley and Whitefield cannot be reduced to a simple evangelical type in content and purpose.

Second, open-air preaching both prior and subsequent to Whitefield and Wesley, has also had a range of content and purposes beyond seeking personal salvation. During the thirteenth century, for example, the mendicant friars were used by the papacy as a 'propaganda machine', to 'preach the cross', with the explicit purpose of getting people to support the Crusades either in person or financially (Maier 1994: 32).

Later, during the fourteenth and fifteenth centuries, such itinerant preachers as a result of their exposure to the needs of the common people were at times instrumental in declaring abuses and stirring people to action. Owst, on the basis of the analysis of sermons from about 1350-1450, claims that the preaching friars were preachers of political and social as well as religious reform (Owst 1926: 80). He states:

In politics, behind the throng of noisy rebels and discontents, whether the rebellion of Simon de Montford, the Peasant Revolt, or the risings which follow the disposition of Richard II, we catch glimpses of passionate eloquent friars stirring men on to resist tyranny or the usurpation which mars the hour (Owst 1926: 55$56)$.

On this matter of content and purpose, Campbell in his essay on open-air preaching also demonstrates that open-air preaching has had the purposes of 'reform', 'reconciliation', 'resistance', and 'solidarity' with the poor (Saunders and Campbell 2000: 96-103). MacLeod's open-air preaching in Govan Glasgow in the 1930s dealt with a range of socio-political issues. Indeed, his preaching embodied 'a counter-performance' to the dichotomy which he considered had been created between the spiritual on one hand and the socio-political on the other (Blythe 2011: 29).

Third, an evangelical passion in the tradition of Whitefield and Wesley need not necessitate a particular narrow content or purpose. A significant British example of an open-air preacher with a breadth of content and 
purpose is the previously mentioned Donald Soper, one of the best known English open-air preachers of the late twentieth century. A Methodist minister, he always understood himself to be one of 'John Wesley's travelling preachers' (Frost 1996: 221). He was an advocate for open-air preaching stating, 'It is an art which should be recovered and an opportunity which we dare not lose' (Soper 1961: 64). He spoke on a huge range of social and political issues including pacifism. He considered such preaching to be 'preevangelistic and apologetic' (Frost 1996: 107). Indeed, he suggested that to ask about the number of converts was not to understand the nature of open-air preaching (Soper 1961: 81). That said, Soper was a man with an evangelistic concern and there were converts through his open-air preaching (Frost 1996: 107). But even for those with such a concern there may have been other purposes and content in their open-air preaching.

To be sure, therefore, people preach in the open-air because of a concern to win other people to Jesus Christ and see the outdoors as providing an audience of those who may never be reached through in-church services. Spurgeon emphasises, "The great benefit of open-air preaching is that we get so many new comers to hear the gospel who otherwise would never hear it' (Spurgeon 1881: 78). This was a feature of the preaching of Wesley and Whitefield. As with their preaching, however, the history of open-air preaching demonstrates far wider content and purposes.

\section{Relationship to Worship}

In addition to the status of the preacher, the location of the event, the content and purposes of the preaching, a further factor of differentiation in open-air preaching has been the relationship of the preaching to other acts of worship. On some occasions, open-air preaching has been embedded in acts of liturgical assembly. Historically this was the case in the Medieval period when the gatherings at which open-air preaching took place were constituted by the Liturgical Calendar (Owst 1926: 194-221). It was also the case with the preaching in the open air that accompanied Scottish open-air Communion Services (Schmidt 1998) and the 'field preaching' of the Covenanters (Blaikie 1888: 155-184). Preaching as part of outdoor services remains one such expression of open-air preaching.

On other occasions, the relationship between open-air preaching and accompanying acts of worship has been more ambiguous. For example, the open-air preaching at St Paul's Cross was accompanied by customary opening and closing prayers and for some time by congregational-psalm singing (MacLure 1958: 9). On behalf of the organisers this may have constituted the assembly as an act of worship. Yet, allowing for the variety of motives and interests associated with the 'spectacle' of particular preaching stations, questions must be raised as to whether those who gathered can be said to 
have been a congregation in worship (MacLure 1958: 8). In turn, Wesley and Whitefield may have accompanied their preaching with prayer and hymn singing but the audiences they preached to were not necessarily congregations (Old 2004: 113-114; Stout 1991: 79). At times these preachers would go to locations where they would seek to gather audiences out of passers-by and / or actively compete for the attention of people over and against other attractions of leisure and entertainment. Stout writes about Whitefield creating a 'hybrid' gathering that was neither, 'sacred or profane' (Stout 1991: 68).

The ambiguity in relationship that can exist between open-air preaching and other acts of worship is demonstrated also in some of the early literature associated with the Open-Air Mission, formed in 1853. Writing in 1855, its founder John MacGregor, in a pamphlet entitled Go Out Quickly, distinguished clearly between a 'worshipping congregation and a listening crowd' (MacGregor 1855: 5, emphasis original). He argues that acts of worship such as hymn singing can be dispensed with and "prayer very briefly employed; more, in fact to gather the audience, and to show the spirit of the work, than to conduct the praise or petitions of those who attend' (MacGregor 1855: 5). Gawin Kirkham, who became secretary of the Open-Air Mission in 1860, allowed for hymn singing to take place, though he understood such and similar acts to function as 'attractions' that can gather a crowd (Kirkham 1888: 64-65). A similar understanding of function, with more intentional theatrics, can be attributed to the open-air preaching events of the Salvation Army, formed in 1865. Writing about the activities of the Salvation Army in the 1880's, Pamela J. Walker states:

Unlike virtually any of their contemporaries, Salvationists appealed to workingclass audiences by borrowing some of the elements of working class culture with a real appreciation of their attractions. The brass bands, music-hall songs, street performances, and daring women all appealed to the senses. The use of such cultural elements was widely called sensationalism (Walker 2001: 198).

In some ways in a similar yet distinct way MacLeod, on one occasion, combined the drama of liturgical procession and parade with open-air preaching activities, perhaps indeed in competition to the theatrics being provided by others, such as the Salvation Army (Blythe 2011: 29-30). The accompaniment of open-air preaching with what may be perceived in other contexts as liturgical acts, therefore, does not mean that they functioned as such in the open air or that the gatherings constituted a congregation gathered in liturgical assembly.

Open-air preaching can also occur apart from any other acts of worship. Soper preached at Tower Hill and Hyde Park without any accompanying worship. He did not assume that he would be addressing a congregation 
gathered in liturgical assembly. In a published lecture on open-air preaching he stated: 'It begins in the recognition that you are there to be shot at. You are there to stand your corner, and to state your case, under conditions where you enjoy nothing of the privilege that normally you can enjoy in the dugout of the pulpit or escape hatch of the vestry' (Soper 1961: 72). He also argues that unless open-air services are large enough to take on the nature of a demonstration, then they can be 'pathetic' and harmful to the gospel. Accordingly, he considered that his own preaching took place in a 'secular' rather than 'spiritual' environment (Soper 1961: 65). Campbell makes a similar point at least in the sense that open-air preaching can take place devoid of attendant institutional support: 'On the streets... all of the institutional trappings of preaching are stripped away. No pulpit offers security; no sanctuary provides a 'safe place'; no ordination grants the preacher status and authority. Rather, preachers must rely on God's Word and the human voice alone' (Saunders and Campbell 2001: 104).

The relationship, therefore, of open-air preaching to other attendant acts of worship has varied considerably. Sometimes this allows what is taking place to be described as a Church worship service outdoors. At other times, however, there have been no other accompanying acts of worship. Indeed, even when such have been present they have not necessarily functioned as such but rather as a means of novelty to gather an audience.

\section{Style}

In this concluding section, discussing the diversity possible in open-air preaching, I want to highlight different individual styles. Edelman writes, 'The act of shouting out a religiously divisive message without invitation, no differentiation, nor concern for its effect, nor effort to mould the means of speech to the context of speaking represents no sort of public hail that Jürgen Habermas would recognise' (Edelman 2013: 117). Edelman's article deals specifically with religious performances in the public space in relation to the understandings of Habermas. However, Edelman describes a particular style of open-air preaching. This style may represent the two or three particular contemporary American examples upon which he focusses. It may also resonate with the dominant stereotype of haranguing preachers who have little concern for passers-by or who do not make any attempt to make common meaning with the audiences they seek to create or gather. Yet, it would be quite inaccurate to suggest that all open-air preaching is or has been of this style, making no 'effort to mould the means of speech to the context of speaking'.

Attention has already been drawn to the differences in style between Wesley and Whitefield. Whitfield's approach can be described as dynamic and theatrical as he competed for audiences: 'The words were a scaffold 
over which the body climbed, stomped, cavorted, and kneeled, all in an attempt-as much intuitive as contrived-to startle and completely overtake his listeners' (Stout 1991: 40). Haldane's actual preaching may have been more restrained than Whitefield's but he made use of 'novelty' by announcing his own sermons through the use of the town hand-bell or drum (Blythe 2015: 36). Spurgeon dedicated a whole lecture to encouraging good preaching with attention to details and avoiding the sort of 'incessant bawling' that Edelman attributes to the preachers he describes (Spurgeon 1881b: 92). MacLeod encouraged a question and answer time as part of at least some of his open-air preaching activities. A response on one such occasion may have led him to forming the Iona community (Ferguson 1990: 138). For Soper, heckling was a necessary part of the communicative dynamic that made this type of preaching work (Soper 1961: 68). The OpenAir Campaigners have made use of an artistic sketch board to gather an audience and maintain interest with adults ever since 1947 until the present day (Duffecy 1983: 81). The point here is not the extent to which these approaches are successful. It is rather to indicate that in terms of the style of presentation as with other factors there is considerable variety in the practice over and against a simplistic stereotypical portrayal.

\section{Conclusion}

Open-air preaching is a minority practice when it comes to the practice of preaching. However, it is a practice which can claim a long history, supported by biblical antecedents and historical examples. Giving an overview of the history of open-air preaching requires collecting data from scattered sources, as popular writings lack depth and analytical dimension, and general histories of preaching often pay limited attention to this specific genre. Beginning with Charles H. Spurgeon's treatises, however, I have sought to develop and bring the discussion up-to-date through critically engaging with a variety of the available sources. Then, in the second half of the article an argument against a purely stereotypical understanding of open-air preaching is developed. It is common knowledge that open-air preaching is associated with evangelism and 'winning souls'. While the desire to evangelise clearly motivates many open-air preachers, the practice is in fact very diverse in terms of its expression as related to a number of variables. The variables, which give the genre dynamic and diversity, include the status of preachers, specific locations where the preaching takes place, as well as the content and purpose. The latter cannot be limited only to evangelistic aims as the examples confirm. In addition, the article argues that relations between open-air preaching and acts of worship are more complex than meets the eye. Sometimes open-air preaching takes the form of a worship service outdoors, but sometimes the acts of worship are missing altogether or their 
function is altered. Preaching style functions also as a variable, and the long history of open-air preaching evidences that 'street-preaching' cannot be identified only with an 'angry style' as it employs a wide range of communicative dynamics.

\section{Bibliography}

Blaikie WG (1888) The Preachers of Scotland: from the Sixth to the Nineteenth Century. Edinburgh: T \& T Clark.

Bliss J, ed (1854) The Works of William Laud, volume 4. Oxford: John Henry Parker.

Blythe S (2009) Open-Air Preaching as Radical Street Performance. PhD Thesis, University of Edinburgh, UK.

Blythe SM (2011) George MacLeod's open-air preaching: Performance and counter-performance. Theology in Scotland 18(1): 21-33.

Blythe S (2015) James Haldane's Open-Air Preaching, 1797-1805. Baptist Quarterly 46(1): 27-43.

Campbell CL (2007) The Preacher as Ridiculous Person: Naked Street Preaching and Homiletical Foolishness. In Academy of Homiletics Papers, pp. 149-158.

Campbell TA (1991) The Religion of the Heart: a Study of European Religious Life in the Seventeenth and Eighteenth Centuries. Eugene, OR: Wipf and Stock.

Christian Institute (2007) The law relating to street evangelism. Online: http://www.christian.org.uk/wp-content/uploads/the-law-relating-tostreet-evangelism.pdf (Accessed 19 June 2017).

Coomes P (2015) http://www.bbc.com/news/in-pictures-32703071 (Accessed 19 June 2017).

Corfield PJ (1995) Power and the Professions in Britain 1700-1850. London: Routledge.

Darby HS (1953) Hugh Latimer. London: Epworth Press.

Dargan EC (1968) A History of Preaching: from the Apostolic Fathers to the G reat Reformers A.D. 70-1572, volume 1. Grand Rapids, MI: Baker Book House. (Reprinted from 1905 edition).

Declaratory Act of the General Assembly of the Church of Scotland, respecting Unqualified Ministers and Preachers (May 28, 1799). In Acts of the General Assembly of the Church of Scotland, 1638-1842. Edinburgh: The Edinburgh Printing and Publishing House, pp. 868-869.

Davies H (1961) Worship and Theology in England: from Watts to Wesley to Maurice, 1690-1850, volume 3. Princeton, NJ: Princeton University Press.

Duffecy JA (1983) The Truceless Warfare Advances. Citrus Springs, FL: Daniels Publishing. 
Edelman J (2013) The Intolerable, Intimate Public of Contemporary American Street Preaching. In Chambers CM, du Toit SW, and Edelman J, Performing Religion in Public. Basingstoke: Palgrave Macmillan.

Edwards A (2017) Kierkegaard as Socratic Street Preacher? Reimagining the Dialectic of Direct and Indirect Communication for Christian Proclamation. Harvard Theological Review 110(2): 280-300.

Edwards OC (2004) A History of Preaching. Nashville, TN: Abingdon Press.

Ewing G (1799) A Defence of Itinerant and Field Preaching: a Sermon Preached Before the Society for Gratis Sabbath Schools, On the 24th of December 1979, In Lady Glenorchy's Chapel, Edinburgh. Edinburgh: J. Ritchie.

Fant CE and Pinson WM (1971) 20 Centuries of Great Preaching: Wesley to Finney, volume 3. Waco, TX: Word.

Ferguson R (1990) George MacLeod: Founder of the Iona Community. London: Harper Collins.

Field DN (2015) John Wesley as a Public Theologian: the Case of Thoughts on Slavery. Scriptura 114(*): 1-13.

Frost B (1996) Goodwill on Fire: Donald Soper's Life and Mission. London: Hodder and Stoughton.

Gibson NC (1984) The Fisherman's Basket: Open-Air and Other Methods of Evangelism. NSW: Mission Publications.

Govan Press (5 November 1937) Peace Week in Govan: Assemblies at New Govan Cross.

Govan Old Parish Magazine (October 1937) The Cross of Govan.

Haldane A (1855) The Lives of Robert Haldane of Airthrey, and of his brother, James Alexander Haldane, 4th edition. Edinburgh: W. P. Kennedy.

Haldane JA, Aikman J, and Rate J (1798) Journal of a Tour Through the Northern Counties of Scotland and the Orkney Isles, in Autumn 1779, Undertaken with a view to Promote the Knowledge of the Gospel of Jesus Christ, 3rd edition. Edinburgh: J. Ritchie.

Hunter GG (1972) Evangelistic Rhetoric in Secular Britain: The Theory and Speaking of Donald Soper and Bryan Green. PhD Thesis, Evanston, Illinois.

Kienzle BM (1998) The Prostitute-preacher: Patterns of Polemic against Medieval Waldensian Women Preachers. In Kienzle BM and Walker PJ (eds) Women Preachers and Prophets through Two Millennia of Christianity. London: University of California Press, pp. 99-113.

Kirkham G (1888) Hints for Beginners. In Godfrey Holden Pike Beneath the Blue Sky: Preaching in the Open-Air London: Hodder and Stoughton, pp. 61-71.

Lewis DM (1986) Lighten Their Darkness: The Evangelical Mission to WorkingClass London, 1828-1860. London: Greenwood Press. 
Lovegrove D (2000) 'A set of men whose proceedings threaten no small disorder': The Society for Propagating the Gospel at Home, 1798-1808. The Scottish Historical Review 79(1): 61-81.

MacClure M (1958) The Paul's Cross Sermons 1534-1642. London: Oxford University Press.

MacGregor J (1855), Go Out Quickly. London: Blackburn and Burt.

Maier CT (1994) Preaching the Crusades: The Mendicant Friars and the Cross in the Thirteenth Century. Cambridge: Cambridge University Press.

Moynahan B (2003) William Tyndale: if God Spare My Life. London: Abacus.

OAC UK. Online: http://www.oacgb.org.uk/ (Accessed 5 July 2017).

Open Air Mission. Online: http://www.oamission.com/ (Accessed 5 July 2017).

Old HO (1998) The Reading and Preaching of the Scriptures in the Worship of the Christian Church: the Biblical Period, volume 1. Grand Rapids, MI: Wm. B. Eerdmans.

Old HO (2004) The Reading and Preaching of the Scriptures in the Worship of the Christian Church: Moderatism, Pietism, and Awakening, volume 5. Grand Rapids: Wm. B. Eerdmans.

Open-Air Evangelism Training Manual (2006). Manchester: OAC.

Osborn RE (1999) Folly of God: the Rise of Christian Preaching: A History of Christian Preaching, volume 1. St Louis, MO: Chalice Press.

Owst GR (1926) Preaching in Medieval England: An Introduction to Sermon Manuscripts of the Period, c. 1350-1450. Cambridge: Cambridge University Press.

'Pastoral Admonition, addressed by the General Assembly of the Church of Scotland, met at Edinburgh, May 23, 1799, to all the People under their Charge', In Acts of the General Assembly of the Church of Scotland, 16381842. Edinburgh: The Edinburgh Printing and Publishing House, pp. $870-873$.

Pike GH (1888) Beneath the Blue Sky: Preaching in the Open-Air. London: Hodder and Stoughton.

Rogers C (1876) Memoir of George Wishart, the Scottish Martyr. With His Translation of the Helvetian Confession, and a Gene-Alogical History of the Family of Wishart. Transactions of the Royal Historical Society, 4.

Saunders SP and Campbell CL (2000) The Word on the Street: Performing the Scriptures in the Urban Context. Grand Rapids, MI: Wm. B. Eerdmans.

Schmidt LE (1989) Holy Fairs: Scottish Communions and American Revivals in the Early Modern Period. Princeton, NJ: Princeton University Press.

Spurgeon CH (1881) Open Air Preaching-A Sketch of its History. In Spurgeon CH, Second Series of Lectures to My Students: Being Addresses Delivered to the Students of The Pastors College, Metropolitan Tabernacle. London: Passmore and Alabaster, pp. 54-75. 
Spurgeon CH (1881b) Open Air Preaching-Remarks Thereon. In Spurgeon CH, Second Series of Lectures to My Students: Being Addresses Delivered to the Students of The Pastors College, Metropolitan Tabernacle. London: Passmore and Alabaster, pp. 76-95.

Soper D (1961) Advocacy of the Gospel. London: Hodder and Stoughton.

Stevenson G and Wright S (2008) Preaching with Humanity. London: Church Publishing House.

Stout, HS (1991) The Divine Dramatist: George Whitefield and the Rise of Modern Evangelicalism. Grand Rapids, MI: Michigan.

Taylor WM (2004) The Scottish Pulpit: From the Reformation to the Present Day Birmingham: Solid Ground Christian Books. (Reprinted from 1887 edition.)

Thompson DD (1998) John Wesley as a Social Reformer. New York, NY: Curts \& Jennings.

Walker PJ (2001) Pulling the Devil's Kingdom Down: the Salvation Army in Victorian Britain. Berkeley, CA: University of California Press.

Webber FR (c1952) History of Preaching in Britain and America: Including the Biographies of Many Princes of the Pulpit and the Men Who Influenced Them, 3 volumes. Milwaukee, WI: Northwestern Publishing House. 